\title{
Acute Traumatic Central Cord Syndrome: Early Decompression or Not?
}

\author{
Insoo Kim \\ Department of Neurosurgery, Keimyung University College of Medicine, Dongsan Medical Center, Daegu, Korea
}

Objective: The purpose of this study is to compare the clinical outcomes of the patients with acute traumatic central cord syndrome (ATCCS) who were managed between early surgical treatment and conservative treatment.

Methods: Between March 2004 and May 2007, 45 patients with ATCCS were treated. 27 patients were treated surgically and 18 patients were treated conservatively. Early decompressive surgery was performed within 24 hours after the trauma in all surgical patients. All patients were admitted within 8 hours of injury and high-dose methylprednisolone was administered. The clinical and radiological data were collected for each patient.

Results: The significant improvement of American Spinal Injury Association (ASIA) score was achieved within the first 6 months of the surgery. There were statistically significant differences $(p<0.05)$ between the surgical and conservatively treated patients at 1, 3 and 6 months follow-ups. However, there were no statistically significant differences of the improvements between two groups at 1 year. The ASIA score improvement had a positive correlation with the age at injury. The patients who were older than 65 years at injury showed statistically lower motor improvement than the patients who were younger than 65 years. The lengths of hospital stay were significantly shorter in patients with surgical treatments $(p<0.05)$ than those in patients without surgery.

Conclusion: Comparing with conservative treatment, early surgical decompression may be associated with rapid neurologic improvement, early mobilization, and shorter periods of hospitalization.

Key Words: American Spinal Injury Association score $\cdot$ Surgical treatment $\cdot$ Central cord syndrome

\section{서 론}

외상성 중심성 척수 증후군(central cord syndrome)은 불완 전 척수증후군의 가장 흔한 형태로, 1887년 처음으로 Thorburn $^{29)}$ 이 보고한 이후, 1954년 Schneider ${ }^{26)}$ 에 의해 “외상성 중심성 척수 증후군은 하지에 비해 상지의 운동기능 손상이 떨어지며, 방광의 기능 부전이 빈번히 동반되고, 손상부위 아 래에서의 감각 소실이 다양한 정도로 나타나는 불완전 척수 손상”으로 정의되어지고 알려지게 되었다. 외상성 중심성 척 수 증후군은 경수 손상의 약 $10 \%$ 에서 $30 \%$ 정도로 보고되고 있으며 ${ }^{17,20,27)}$, 발병 원인으로 추락, 교통사고, 폭행, 다이빙,

- Received: Mar 21, 2011 - Accepted: Mar 29, 2011

- Published: Mar 30, 2011

Corresponding Author: Insoo Kim, MD, PhD

Department of Neurosurgery, Dongsan Medical Center, 194 Dongsan-

dong, Jung-gu, Daegu 700-712 Korea

Tel: +82-53-250-7730, Fax: +82-53-250-7356

E-mail: neurokim@dsmc.or.kr

*The present research has been conducted by the Bisa Research Grant of Keimyung University in 2007
낙하하는 물체에 의한 손상 등이 포함되므로 어느 연령층에 서도 발생가능하나 주로 활동이 많은 장년층과 경추 척추증 (cervical spondylosis)을 동반한 노인환자에서 과신전에 의해 잘 발생하는 것으로 알려져 있다, $2,13,15-17,23-26)$.

대부분의 환자들은 자발적인 호전을 보이고, 여러 수술적 인 치료가 척수의 손상을 더욱 악화시킬 수도 있다는 우려로 인해 보존적 치료가 우선적으로 시행되어 왔다. 그러나 외상 성 중심성 척수 증후군의 자연경과에서 손상 초기에는 증상 이 호전되다가 일정한 고원부(Plateau)를 이루는 것이 아니고, 어느 시점 이후에는 악화되는 것을 자주 볼 수 있다. 1971년 Bosch 등은 보존적 치료를 받은 환자 중 장기적인 추적 관찰 에서 $60 \%$ 정도만 기능 회복을 유지하였고, $25 \%$ 의 환자들은 만성 척수병증의 결과에 의해 점차 기능적인 악화를 보여 보 행이 불가능한 상태를 보인 것으로 보고하였다. 수술적 치료 의 효과에 대해 Bose 등 ${ }^{3}$ 은 14 명의 수술적 치료군과 14명의 보존적 치료군에서 퇴원 시 수술적 치료군에서 보다 기능적 인 회복이 좋았다고 보고하였으나 관찰 기간이 너무 짧다는 제한이 있었다. 최근에는 조기 수술적 치료의 유익성에 대한 여러 보고들이 중심성 척수 손상의 치료에서 논란을 야기하 
고 있다 ${ }^{7,12,20,31)}$. 그리고 수술적 치료의 시기에 대해서는 혈류 역학적 변수(hemodynamic parameters)가 조절되고 능숙한 수술과 마취가 이루어 진다면 조기 수술이 안전하고 효과적 이라는 보고 ${ }^{11)}$ 도 있어 조기 수술의 효과에 대한 기대는 더욱 커지고 있다. 급성 외상성 중심성 척수 증후군 환자에서 수상 후 24시간 이내의 조기 수술적 치료와 보존적 치료에 대한 비교 분석한 결과에 대해서 아직 충분한 조사 및 연구가 이루 어진 바 없어, 본 연구에서는 급성 외상성 중심성 척수 증후군 45 명의 환자에서 조기 수술적 치료 환자와 보존적 치료를 시행한 환자의 임상 결과를 비교하고 분석하여 문헌고찰과 함께 보고하고자 한다.

\section{대상 및 방법}

\section{1. 대 상}

연구는 후향적으로 조사한 방사선 영상, 환자 기록지 등의 자료를 바탕으로 2004년 3월부터 2007년 5월까지 본원 응급 실 도착 당시 하지에 비해 상지의 운동기능 손상이 떨어지며, 방광의 기능 부전이 빈번히 동반되고, 손상부위 아래에서의 감각소실이 다양한 정도로 나타나는 불완전 척수 손상으로 정 의되어지는 외상성 중심성 척수 증후군 환자들 중 수상 이후 8 시간 이내 응급실에 도착하였고, 추적 관찰이 가능하였던 45 명의 환자를 대상으로 비교분석 하였다. 이중 보존적 요법을 시행한 환자 그룹이 18 명이었으며, 수상 후 24 시간 이내의 조기 수술적 치료를 시행한 환자 그룹이 27 명이었다.

\section{2. 방 법}

45 명의 모든 환자들에서 수상 후 8 시간 이내에 스테로이드 대량요법 ${ }^{4}$ 을 시행하였으며, 모든 수술은 수상 후 24시간 이 내에 시행하였다. 수술의 적응증은 신경학적 증상의 결손과 연관된 부위에서 척수를 지속적으로 압박하고, 척수 내 손상 의 영상의학적인 소견을 보이거나, 경추의 불안정성을 지닌 급성 외상성 중심성 척수 증후군으로 진단된 환자를 대상으 로 하였으며, 상완 신경총 손상, 말초신경 손상, 분리된 경추 신경근 손상, 상지의 골절, 뇌의 손상과 만성 척수병증의 기왕 력 등이 동반된 경우는 제외하였다.

대상 환자들의 성별, 수상 당시 연령, 수상의 원인, 수상의 형태, 수상 후부터 수술적 치료가 이루어진 시간의 간격, 수상 부위, 수술 치료의 형태(전방, 후방 경유 또는 복합), 수술 후 합병증, 입원 기간 그리고 재활 기간에 대해 분석하였다.

치료 후 기능적 회복 정도는 ASIA motor score를 기준으로
입원 시, 1 개월, 6 개월, 1 년, 마지막 관찰 시에 각각 평가하였 고 $^{18)}$, Walking Index for Spinal Cord Injury (WISCI) scale(점 수범위 $0-20$ )을 1 개월, 6 개월, 1 년, 마지막 관찰 시에 각각 평가하여 분석하였다 ${ }^{211}$.

수상의 원인은 교통사고, 추락, 스포츠손상, 기타 등의 4 그룹으로 나누어 조사하였다.

수상의 형태는 일반 방사선 검사, 전산화단층촬영, 자기공 명영상 등을 근거로 급성 추간판탈출, 골절 혹은 탈구가 동반 된 경우, 척추증과 같은 다분절 퇴행성변화의 병변, 후방인대 골화증 등의 그룹으로 나누어 조사하였다. 수술적 치료는 전 방경유, 후방경유, 또는 전· 후방 감압 및 유합술의 세 가지로 분류하였다. 전방경유 수술적 치료는 단분절 추간판탈출, 추 체 골절로 인한 척수의 전방압박, 큰 골극, 후종인대골화증이 나 척추증성 협착(spondylotic stenosis)이 2분절 이하에서 있 는 경우 시행하였고, 후방경유 수술적 치료는 3 분절 이상의 척추관 협착이 있거나 후방압박이 있는 경우에 시행하였다. 본 연구에서는 전·후방 복합경유의 경우는 없었다(Fig. 1, 2).

통계학적 분석은 수집된 자료는 SPSS 16.0 통계 프로그램 을 사용하여 전산통계 처리하였으며, 유의수준 5\%에서 검정 하였다. 보존적 요법을 시행한 그룹과 수술적 치료를 시행한 그룹에 따른 연령, 입원 기간, 재활치료 기간, ASIA motor score 를 비교하고자 t-test를 실시하였고, 응급실 내원 당시와 관찰 기간별 ASIA motor score와 WISCI scale의 차이는 paired t-test를 이용하여 검정을 실시하였고, 65 세 미만 그룹과 65 세 이상의 그룹 간의 운동회복의 정도는 선형회귀분석으로 비교 하였다.

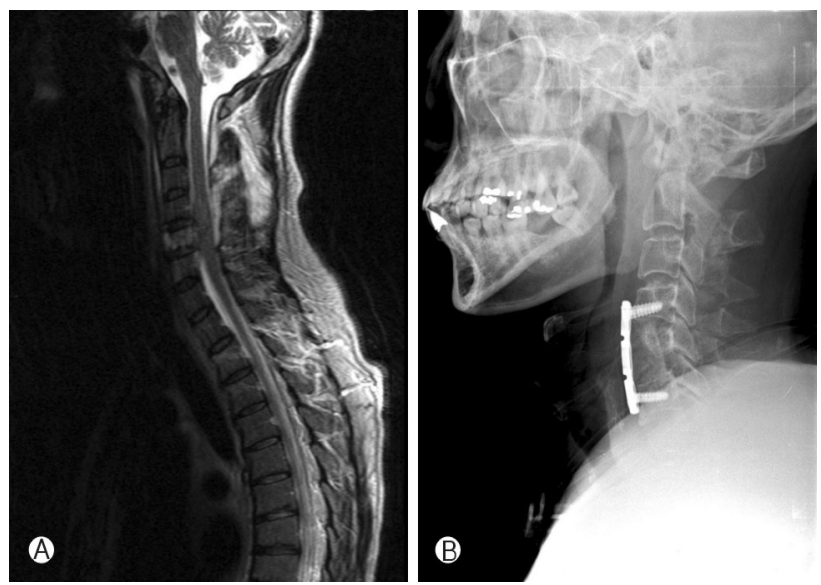

Fig. 1. Imaging studies obtained from a 64-year-old man injured in a traffic accident. A: Preoperative sagittal MR image demonstrating compression fracture of $\mathrm{C} 5$ with cord compression and an intramedullary high signal intensity. B: Radiographs obtained after anterior decompression and iliac bone graft with instrumentation. 


\section{결 과}

45명의 급성 외상성 중심성 척수증후군 환자들 중 보존적 요법을 시행한 환자 그룹에서 남자는 13 명, 여자는 5 명, 평균 나이는 64.7(53-75)세였으며, 수술적 치료를 시행한 환자 그룹 에서 남자는 18명, 여자는 9명, 평균 나이는 61.4(48-75)세였다.

수상의 원인으로는 두 그룹에서 모두 교통사고가 가장 많았 고, 다음으로 추락과 운동 중 외상을 입은 경우였다. 수상의 형태에서는 두 그룹에서 퇴행성 변화에 의한 경추 척추증이 가장 많았으며, 다음으로 후종 인대 골화증이 많았다(Table. 1).

평균 추적기간은 보존적 요법을 시행한 환자 그룹에서 34.27 개월, 수술적 치료를 시행한 환자 그룹에서 28.32개월 이었다. 수술적 치료를 시행한 그룹에서 수상 후부터 수술시 작까지 걸린 시간은 평균 16.45 시간 이었으며, 전방경유 수술 은 9명으로 이중 단분절 전방경유 추간판제거 및 유합술이 4 명, 2 분절 전방경유 추간판제거 및 유합술이 2명, 전방경유 추체제거 및 2 분절 유합술이 3 명이었으며, 후방경유 수술은 18 명으로 모두 후궁성형술을 시행하였다(Table. 2). 척수 손상 부위는 보존적 요법을 시행한 환자 그룹에서는 제 $3 / 4$ 경추 부위 에서 가장 많이 발생하였으며, 수술적 치료를 시행한 환자 그룹 에서는 제 4/5경추 부위에서 가장 많이 발생하였다(Fig. 3).

평균 입원기간의 차이는 보존적 요법을 시행한 환자 그룹 에서 58.04 11.67 일, 수술적 치료를 시행한 환자 그룹에서 $39.35 \pm 9.22$ 일로 수술적 치료를 시행한 그룹에서 통계학적인 유의성이 있게 더 짧았다. 평균 재활치료 기간의 차이는 보존
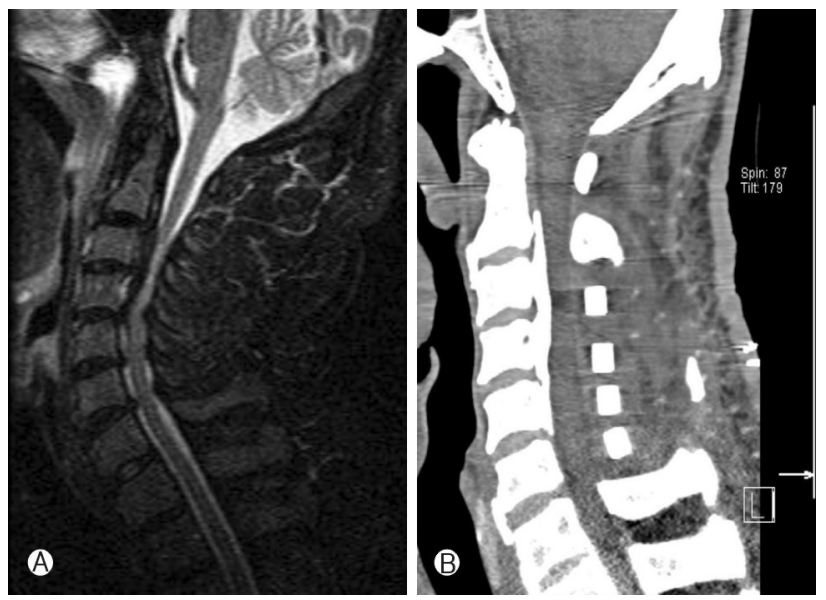

Fig. 2. Imaging studies obtained from a 59-year-old man injured in a fall down. A: Preoperative sagittal MR image demonstrating ossification of posterior longitudinal ligament of C2-5 with cord compression and an intramedullary high signal intensity. B: CT obtained after laminoplasty.
적 요법을 시행한 환자 그룹에서 $131.36 \pm 19.18$ 일, 수술적 치료를 시행한 환자 그룹에서 89.27士17.59일로 수술적 치료 를 시행한 그룹에서 더 짧았으며, 그룹간 통계학적인 의의가 있었다.

Table 1. Summary of patients of 27 surgical and 18 conservative treatment

\begin{tabular}{lcc}
\hline \hline & Surgical & Conservative \\
\hline No. of patients & 27 & 18 \\
Male/female & $18 / 9$ & $13 / 5$ \\
Average of age & $61.37 \pm 13.28$ & $64.74 \pm 11.43$ \\
Causes of injury & & \\
Traffic Accident & 17 & 11 \\
Fall from height & 9 & 6 \\
Sports injury & 1 & 1 \\
Types of injury & & \\
Acute disc herniation & 3 & 0 \\
Fracture and/or dislocation & 3 & 0 \\
Spondylosis & 12 & 16 \\
OPLL & 9 & 2 \\
\hline
\end{tabular}

Table 2. Summary of patients of 27 surgical and 18 conservative treatment

\begin{tabular}{lcc}
\hline \hline & Surgical & Conservative \\
\hline $\begin{array}{l}\text { Average Interval between } \\
\text { Injury \& Surgery }\end{array}$ & & \\
Average of Follow-up & $28.32 \pm 6.57$ (hours) & \\
Months & & $34.27 \pm 11.09$ \\
Surgical Management & 9 & \\
Aniterior approach & 4 \\
1 level ACDF & 2 \\
2 level ACDF & 3 \\
2 level fusion with & \\
$\quad$ corpectomy & 18 \\
Posterior approach & 18 \\
Double-door & \\
Laminoplasty &
\end{tabular}

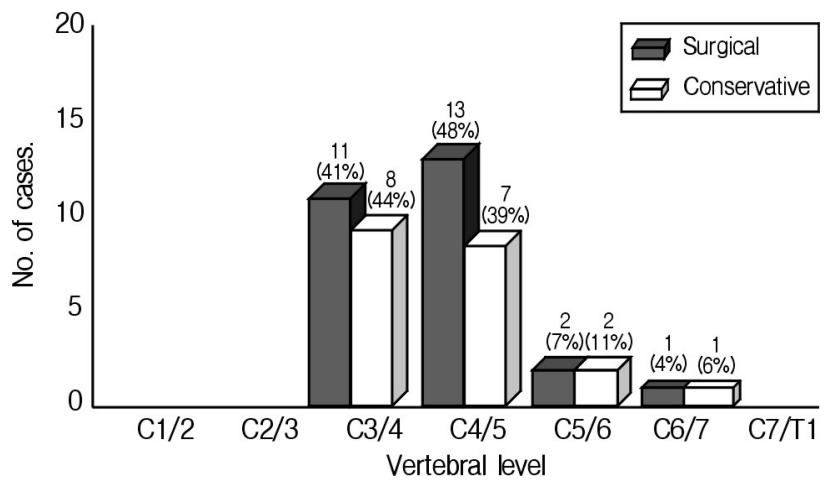

Fig. 3. Bar graphs showing the distribution of injured vertebral levels in each group. 


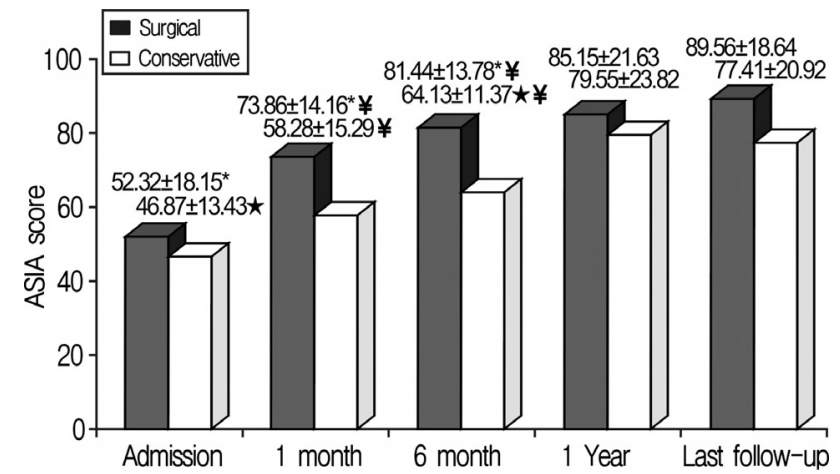

$\star p<0.05$ (paired t-test)

$\star p<0.05$ (paired t-test)

$¥ p<0.05$ (t-test)

Fig. 4. Bar graphs showing differences of admission and followup ASIA motor scores.

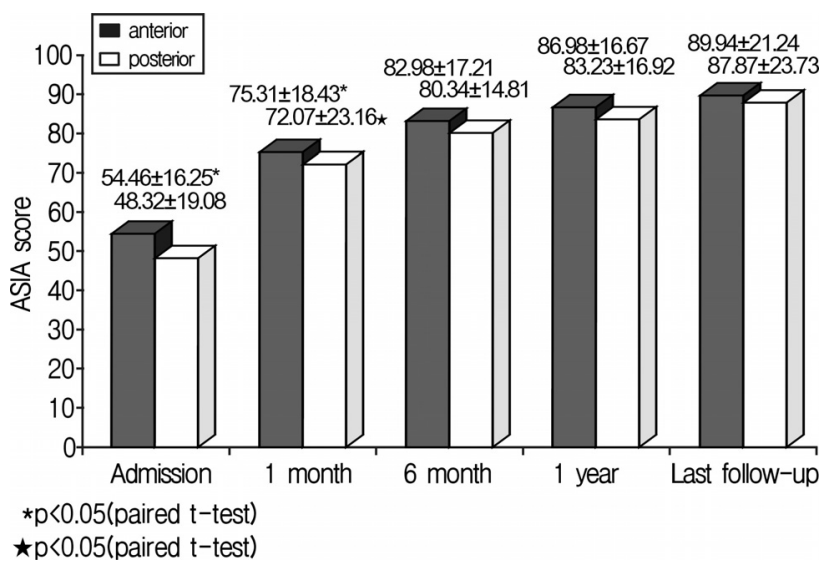

Fig. 5. Bar graphs showing differences of admission and followup ASIA motor scores of surgical approaches.

ASIA motor score의 기간별 차이는 보존적 요법을 시행한 환자 그룹에서는 응급실 도착 당시와 비교하여 6 개월이 지난 시점, 수술적 치료를 시행한 환자 그룹에서는 1 개월이 지난 시점에서 통계학적 유의성을 지닌 호전을 보여 수술적 치료 그룹에서 보다 빠른 호전을 보였으며, 두 그룹간에서 치료 후 1 개월과 6 개월까지는 수술적 치료 그룹에서 보다 나은 통계학적 유의성을 지닌 호전을 보였으며, 6개월 이후부터 마지막 추적 관찰 때까지는 통계학적 유의성은 없었으나, 보 다 높은 평균 ASIA motor score를 보였다(Fig. 4).

수술적 치료 그룹에서 전방경유 그룹과 후방경유 그룹 모 두 응급실 도착 당시와 비교하여 1 개월이 지난 시점부터 통계 학적 유의성을 지닌 호전을 보였으나, 두 그룹의 추적 시점간 의 통계학적인 차이는 없었다(Fig. 5). 그리고 보행 척도인 WISCI scale의 호전 정도를 비교해 본 결과 두 그룹간의 유의 한 차이는 없었다(Fig. 6).

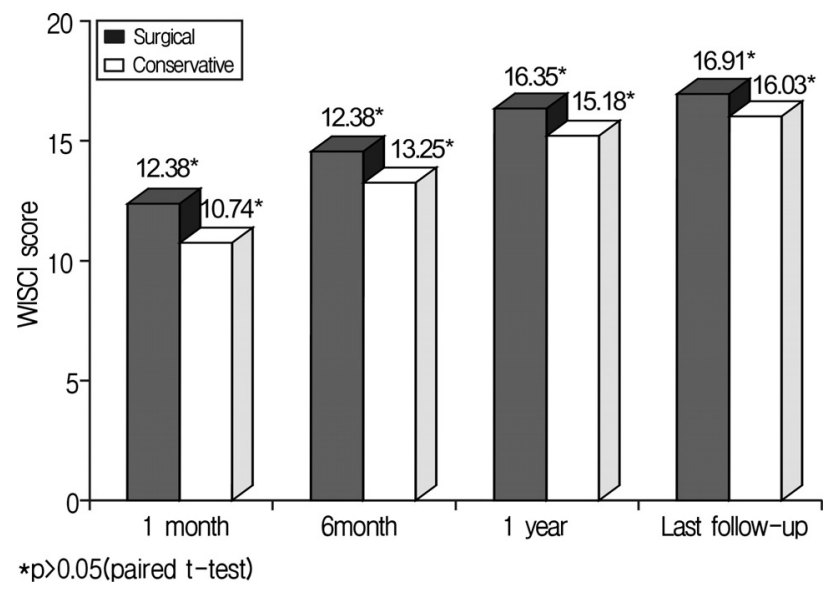

Fig. 6. Summary of follow-up WISCl scores.

전체 외상성 중심 척수증후군 환자에서 수상 당시의 연령에 대한 ASIA motor score의 호전 정도는 상관관계가 있는 것으로 나타나 $(\mathrm{r}=0.503, \mathrm{p}=0.035)$ 65세 이상의 그룹에 비해 65세 미 만의 보다 젊은 그룹에서 ASIA motor score가 더욱 호전되었다. 그리고, 수술적 치료로 인한 특별한 합병증은 없었다.

\section{고 찰}

외상성 중심성 척수 증후군은 임상적인 개념이며, 해부학 적 개념으로는 손상이 주로 척수의 중심부에 집중되어 있음 을 암시한다 ${ }^{20)}$. 중심 척수 증후군의 병태생리학적인 논란은 수 년간 지속되어 왔는데, 상지의 기능이 하지보다 좋지 못한 이유에 대해 Schneider 등 ${ }^{26}$ 은 척수 내의 피질척수로(corticospinal tract)의 내측 섬유들의 선택적인 손상에 의해 척수 내 의 중심부 척수내출혈(hematomyelia)로 인한 것으로 주장하 였다. 그러나 Uribe 등 ${ }^{30)}$ 은 인체 부검을 통해 전형적인 척수내 출혈은 명확하지 않으며, 병리학적인 분석에서 대부분은 미 만성, 후방 및 측방, 그리고 백색질의 손상이 있음을 보여주었 고, 이러한 소견은 자기공명영상에서도 잘 볼 수 있었다. 하지 에 비해 상대적인 상지의 기능 손상은 해부학적으로 피질척 수로에 체성순서적 배열(somatotopic organization)이 존재하 여 척수의 중심부 손상 시에 중심부에 인접한 상지를 지배하 는 신경이 손상받기 쉽기 때문인 것으로 추론되어 왔으나, 원숭이 등의 영장류에 대한 실험에서 이와 같은 해부학적인 구조, 즉 체성순서적 배열이 뇌교 이하 부위에서는 관찰되지 않아 하지에 비해 상대적인 상지의 기능 저하를 설명할 다른 가정들이 대두되었다 ${ }^{13,15)}$. 다른 연구에 의하면 피질척수로에 서 굵은 직경과 가는 직경의 축삭(axon)이 골고루 분포하는 데, 이중 굵은 직경의 축삭이 주로 상지의 원위부 근육을 지배 하는 알파 운동신경세포(alpha motoneuron)에 직접 연결되 
어 있으므로 외상을 받았을 때 굵은 직경의 축삭이 더 많이 손상을 받게되어 상지의 기능이 상대적으로 더 저하된다고 설명하고 있다 ${ }^{15)}$. 따라서 피질척수로의 주요 기능은 주로 상지 특히 손의 기능에 중요한 역할을 담당하기 때문에 경추부 또 는 연수의 추체(medullary pyramids) 부위의 손상, 중심부 뿐 만 아니라, 광범위한 손상이 있을 경우에도 주로 상지쪽의 기능 이상이 두드러지는 중심성 척수 증후군이 발생 가능하 다는 것이다. 최근의 신경병리학적 연구에서는 대부분 굵고, 단일연접(monosynaptic)이며, 급속 전도(conducting)인 말이 집 피질척수(myelinated corticospinal) 섬유들의 손상에 의해 중심 척수 증후군의 발생된다는 가설도 제시되고 있다 ${ }^{14)}$.

보존적 혹은 수술적 치료가 환자의 예후에 미치는 영향에 대한 연구에서 Schneider 등 ${ }^{26}$ 은 중심성 척수 증후군은 척수 의 부종이 호전되면서 운동기능이 회복되어 상당히 좋은 예 후를 보이기 때문에 수술적 치료는 금기 시 하였는데, 실제 당시의 척추궁 절제 수술 환자 중 일부에서 술 후 악화된 경우 가 많이 있었기 때문이었다. 이런 이유로 Schneider 등 ${ }^{26}$ 에 의한 중심성 척수 증후군에 대한 보존적 치료 방법은 1970년 대 초반까지 일반적인 치료 방법으로 받아들여 졌다. 그러나, Bosch 등레 에해 보존적 치료 후 처음에 호전을 보였던 환자 중 $60 \%$ 만이 호전된 상태로 지속이 되고, 나중에는 악화된다 는 연구가 발표되었다. Newey 등 22)은 32명의 중심성 척수 증후군 환자들을 보존적 요법으로 치료 후 평균 8.6년의 추적 관찰 후 퇴원 시의 ASIA 운동점수가 대부분 유지되었으나, 70세 이상의 노인환자들에서는 악화되었다고 보고하였다. 최근 여러 저자들 ${ }^{1,6,9,928)}$ 은 선택적 경우에서 환자의 운동기능 이 나쁜 상태가 지속되는 경우에 척수를 압박하는 해부학적 구조물을 조기에 제거하는 수술적 치료의 유용성에 대해 주 장함으로 치료의 다양성과 함께 논란을 야기하고 있다. Duh 등 $^{10)}$ 은 척수와 신경근의 조기 감압으로 신경학적 회복을 향 상시켜 조기 재활을 유도할 수 있고, 척추의 안정성을 확보함 으로 추가적인 척수손상과 신경학적 악화를 방지할 수 있다 는 이유로 수술적 치료의 유용성을 주장하였다. 본 연구에서 도 외상성 중심 척수 증후군의 수술적 치료에서 신경학적 임 상소견과 영상의학적 소견을 검토하여 신경학적 증상부위와 연관된 척수를 지속적으로 압박하는 해부학적 구조물이 있거 나, 경추의 불안정성이 있는 경우에 수술적 요법을 시행하였 다. Bose 등 ${ }^{3}$ 은 보존적 치료와 수술적 치료의 두 군에서 모두 의미있는 호전을 보였으며, 특히 수술적 치료에서 더 큰 호전 을 보였다고 보고하였으나, 불안정성이 있는 환자에서만 수 술적 치료를 시행하였기 때문에 환자 대상 선택에 제한이 있 었다. Chen 등 ${ }^{8}$ 은 아급성기의 수술은 감각과 운동 기능의 회복을 장 - 단기적으로 호전시키며, 특히 60세 이하의 군에
서는 수술적 치료가 빠른 운동의 회복을 유도하는 것으로 보 고하였다. 또한 Guest 등 ${ }^{12)}$ 은 급성 추간판탈출 또는 골절환자 에서 지연 수술에 비해 24시간 이내의 조기 수술적 치료가 중환자실 입원 및 전체 입원기간이 단축되고, 전반적인 운동 기능의 호전을 보여 보다 안전하고 경제적이라는 보고를 하 였다. 본 연구에서는 지연 수술과의 비교는 없었으나, 보존적 치료와 비교하여 수술적 치료를 통해 운동기능의 빠른 회복 으로 욕창이나, 폐렴 등의 합병증의 발생 가능성을 낮출 수 있었으며, 입원기간과 재활기간의 단축으로 보다 경제적인 효과를 볼 수 있었다.

수상 당시의 연령과 연관된 예후에 대한 여러 연구 ${ }^{9,22-25)}$ 가 있었는데, Newey 등 ${ }^{22}$ 은 70세 이상의 노인환자들에서는 예 후가 불량하였다고 보고하였으며, Roth 등 ${ }^{25}$ 과 Penrod 등 ${ }^{23)}$ 도 연령이 많을수록 기능적 예후에 악 영향을 미친다고 보고 하였다. 이러한 결과는 노인 환자들에서 경추 척추증과 혈관 의 죽상경화(atherosclerotic) 변화로 인한 척수 경색의 발생 가능성이 보다 높기 때문에 신경학적 회복에 보다 좋지 못한 예후를 보이는 것으로 생각된다. 그리고 노인 환자들에서 예 후가 불량한 것은 합병증의 이환율이 보다 높은 경향이 있기 때문인 것으로 생각된다. 본 연구에서도 연령과 운동기능의 회복 정도에서 상관관계가 있는 것으로 나타났는데, 65 세 이 상의 그룹에 비해 65 세 미만의 보다 젊은 그룹에서 ASIA motor score가 더욱 호전되었다.

보행의 회복 정도에 관한 Maynard 등 ${ }^{19}$ 의 연구에서 중심 성 척수증후군 환자의 $90 \%$ 이상에서 사회생활을 위한 보행 이 가능하다고 하였다. 그러나 Bosch 등'이 42 명의 중심성 척수 증후군 환자를 10 년간 추적 관찰한 결과, 퇴원 시에는 $77 \%$ 의 환자에서 보행이 가능하였지만, 오랜 시간이 경과하 면서 $60 \%$ 미만의 환자에서만 보행이 가능한 것으로 보고하 였고, 42 명 중 10 명은 경직이 증가하고 추체로가 침범되는 양상을 보이고, 7 명의 환자에서는 퇴원 시에는 기능적 보행이 가능하였으나, 일정시간 경과 후에는 신경학적으로 악화되어 의자차에 의존하게 되었다고 보고하였다. 본 연구의 결과에 서는 손상 후 1 개월에 보존적 치료 군에서 $39 \%$, 수술적 치료 군에서 $48 \%$ 의 환자가 보행이 가능하였고, 손상 후 1 년이 지 나서는 보존적 치료 군에서 $83 \%$, 수술적 치료 군에서 $85 \%$ 의 환자가 보행이 가능하였다. 지금까지 발표된 연구들과 본 연 구에서 보이는 차이는 연구의 대상군이 크지 않고, 추적 관찰 시기의 차이에 기인한 것으로 생각된다.

본 연구는 후향적으로 진행한 연구이기 때문에 결과에 영 향을 미칠 수 있는 요소들을 배제하고 관리할 수 없었으며, 연구 대상의 숫자가 적고, 비교 대조군 또한 적었다는 제한을 지니고 있다. 그리고, 장기적 추적 관찰이 이루어 지지 못하였 
고, 중심성 척수 증후군 환자의 특성 중 상지의 기능, 특히 수부 기능의 평가에 대한 정확한 평가가 이루어지지 않아 이 에 대한 조사가 불가능하였다는 제한이 있다. 그러나, 이러한 제한에도 불구하고, 급성 외상성 중심성 척수 증후군 환자에 서 정확한 진단과 영상의학적인 소견을 토대로 주의 깊게 대 상 환자를 선택함으로 신경학적 결손이 있는 부위와 연관된 지속적으로 척수를 압박하는 해부학적 구조물과 불안정성에 대한 조기 수술적 치료는 비교적 안전하게 이루어질 수 있으 며, 적절한 치료 방법이 될 것으로 기대된다.

\section{결 론}

급성 외상성 중심성 척수증후군 환자에서 수술적 치료는 특별한 합병증이 없이 안전하게 이루어질 수 있으며, 보존적 치료에 비해 수술적 치료는 ASIA motor score에서 추적 관찰 6개월 시점까지 통계학적으로 유의한 호전을 보였다. 수상 당시의 연령에 대한 ASIA motor score의 호전 정도는 상관관 계가 있는 것으로 나타났다. 따라서, 보존적 요법에 비해 24시 간 이내의 조기 수술적 요법은 보다 빠른 신경학적 호전을 기대 할 수 있으며, 조기운동을 통한 보다 짧은 입원기간과 재활치료 기간과 함께, 경제적 효과 또한 기대된다.

\section{REFERENCES}

1. Aito S, D’Andrea M, Werhagen L, Farsetti L, Cappelli S, Bandini B, et al: Neurological and functional outcome in traumatic central cord syndrome. Spinal Cord 45:292-297, 2007

2. Bosch A, Stuffer ES, Nickel VL: Incomplete traumatic quadriplegia: a ten-year review. JAMA 216:473-478, 1971

3. Bose B, Northrup BE, Osterholm JL, Cotler JM, DiTunno JF: Reanalysis of central cervical cord injury management. Neurosurgery 15:367-372, 1984

4. Bracken MB: Methylprednisolone and acute spinal cord injury: an update of the randomized evidence. Spine 26(24 Suppl): 47-54, 2001

5. Breig A, Turnbull I, Hassler O: Effects of mechanical stresses on the spinal cord in cervical spondylosis: a study on fresh cadaver material. J Neurosurg 25:45-56, 1966

6. Brodkey JS, Miller CF Jr, Harmody R: The syndrome of acute central cervical spinal cord injury revisited. Surg Neurol 14: 251-257, 1980

7. Chen TY, Dickman CA, Eleraky M, Sonntag VK: The role of decompression for acute incomplete cervical spinal cord injury in cervical spondylosis. Spine 23:2398-2403, 1998

8. Chen TY, Lee ST, Lui TN, Wong CW, Yeh YS, Tzaan WC, et al: Efficacy of surgical treatment in traumatic central cord syndrome. Surg Neurol 48:435-440, 1997

9. Dai LY, Jia LS: Central cord injury complicating acute cervical disc herniation in trauma. Spine 25:331-336, 2000

10. Duh MS, Shepard MJ, Wilberger JE, Bracken MB: The effectiveness of surgery on the treatment of acute spinal cord injury and its relation to pharmacological treatment. Neurosurgery 35:240-248, 1994

11. Fehlings MG, Perrin RG: The timing of surgical intervention in the treatment of spinal cord injury: a systemic review of recent clinical evidence. Spine (11 Suppl) 31:28-35, 2006

12. Guest J, Eleraky MA, Apostolides PJ, Dickman CA, Sonntag VK: Traumatic central cord syndrome: results of surgical management. J Neurosurg (1 Suppl) 97:25-32, 2002

13. Hopkins A, Rudge P: Hyperpathia in the central cervical cord syndrome. J Neurol Neurosurg Psychiatry 36:637-642, 1973

14. Jimenez O, Marcillo A, Levi AD: A histopathological analysis of the human cervical spinal cord in patients with acute traumatic central cord syndrome. Spinal Cord 38:532-537, 2000

15. Levi $\mathrm{AD}$, Tator $\mathrm{CH}$, Bunge RP: Clinical syndromes associated with disproportionate weakness of the upper versus the lower extremities after spinal cord injury. Neurosurgery 38:179-185, 1996

16. Maroon JC, Abla AA, Wilberger JI, et al: Central cord syndrome. Clin Neurosurg 37:612-621, 1991

17. Martyn LN, Pradeep KS, Robert DF: The long-term outcome after central cord syndrome. J Bone Joint Surg 82-B:851-855, 2000

18. Maynard FM Jr, Bracken MB, Creasey G, Ditunno JF Jr, Donovan WH, Ducker TB, et al: International standards for neurological classification of spinal cord injury. Spinal Cord 35:266-274, 1997

19. Maynard FM, Reynolds GG, Fountain S, Wilmot C, Hamilton R: Neurologic prognosis after traumatic quadriplegia. Threeyear experience of California Regional Spinal Cord Injury Care System. J Neurosurg 50:611-616, 1979

20. Merriam WF, Taylor TKF, Ruff SJ, Mcphail MJ: A reappraisal of acute traumatic central cord syndrome. J Bone Joint Surg Br 68:708-713, 1986

21. Morganti B, Scivoletto G, Ditunno P, Ditunno JF, Molinari M: Walking index for spinal cord injury (WISCI): criterion validation. Spinal Cord 43:27-33, 2005

22. Newey ML, Sen PK, Fraser RD: The long-term outcome after central cord syndrome: a study of the natural history. J Bone Joint Surg Br 82:851-855, 2000

23. Penrod LE, Hegde SK, Ditunno JF Jr: Age effect on prognosis for functional recovery in acute traumatic central cord syndrome. Arch Phys Med Rehabil 71:963-968, 1990

24. Rand RW, Crandall PH: Central spinal cord syndrome in hyperextension injuries of the cervical spine. J Bone Joint Surg 44-A:1415-1422, 1962

25. Roth EJ, Lawler MH, Yarkony GM: Traumatic central cord syndrome: clinical features and functional outcomes. Arch Phys Med Rehabil 71:18-23, 1990

26. Schneider RC, Cherry G, Pantek H: The syndrome of acute central cervical spinal injury: with special reference to the mechanisms involved in hyperextension injuries of the cervical spine. Neurosurgery 11:546-577, 1954

27. Shrosbree RD: Acute central cervical spinal cord syndrome: 
aetiology, age incidence and relationship to the orthopaedic injury. Paraplegia 14:251-258, 1977

28. Song J, Mizuno J, Inoue T, Nakagawa H: Clinical evaluation of traumatic central cord syndrome: emphasis on clinical significance of prevertebral hyperintensity, cord compression, and intramedullary high-signal intensity on magnetic resonance imaging. Surg Neurol 65:117-123, 2006

29. Thorburn W: Cases on injury to the cervical region of the spinal cord. Brain 9:510-543,1887

30. Uribe J, Green BA, Vanni S, Moza K, Guest JD, Levi AD: Acute traumatic central cord syndrome-experience using surgical decompression with open-door expansile cervical laminoplasty. Surg Neurol 63:505-510, 2005

31. Yamazaki T, Yanaka K, Fujita K, Kamezaki T, Uemura K, Nose T: Traumatic central cord syndrome: analysis of factors affecting the outcome. Surg Neurol 63:95-100, 2005 